\title{
РАЗВИТИЕ КЛОНИРОВАННЫХ ЭМБРИОНОВ КРУПНОГО РОГАТОГО СКОТА in vitro В ЗАВИСИМОСТИ ОТ ПАРАМЕТРОВ СЛИЯНИЯ И АКТИВАЦИИ
}

\author{
Г.Н. СИНГИНА, А.В. ЛОПУХОВ, Е.Н. ШЕДОВА
}

Технология получения клонированных эмбрионов крупного рогатого скота имеет широкие перспективы применения для решения задач, направленных на тиражирование высокопродуктивных и уникальных генотипов в племенном животноводстве, а также создание новых генотипов методами геномного редактирования. Известно, что основой успешного клонирования является способность донорского ядра соматической клетки перепрограммироваться в направлении тотипотентного состояния и что соответствующие трансформации ядра клетки (кариопласта) опосредуются факторами цитоплазмы ооцита (цитопласта) и начинаются с момента их объединения (слияния). При этом характер воздействия цитоплазмы зависит от многих факторов и является объектом направленного воздействия. В этой связи в рамках представляемой работы была поставлена цель оценить эффективность клонирования с точки зрения продолжительности воздействия цитоплазмы ооцита на донорское ядро до активации, возраста МІІ ооцитов на момент их активации в составе слившихся комплексов (цитогибридов), а также повторного электрослияния цитопласта и кариопласта. Изучали воздействие указанных факторов на формирование клонированных эмбрионов и их развитие до стадии бластоцисты. Выделенные post mortem ооцит-кумулюсные комплексы (ОКК) созревали в среде ТС-199, дополненной $10 \%$ фетальной бычьей сыворотки, 10 мкг/мл фолликулостимулирующего (ФСГ) и 10 мкг/мл лютеинизирующего (ЛГ) гормонов. Через 20-24 ч созревания ОКК обрабатывали 0,1\% раствором гиалуронидазы, механически удаляли кумулюсные клетки и отбирали ооциты с первым полярным тельцем. Фетальные фибробласты (длительного срока хранения) культивировали до сформированного монослоя, контактно ингибировали в течение 2 сут и готовили к процедуре переноса в энуклеированный ооцит в виде суспензии. Для объединения ооцитов и перенесенных в их перивителлиновое пространство клеток применяли два последовательных прямоугольных импульса постоянного тока при напряжении 35 В продолжительностью 20 мкс (однократно или в случае отсутствия признаков объединения клеток двукратно). Полученные цитогибриды активировали иономицином через 1,0 или 2,0 ч после слияния (23-25 или 26-28 ч с момента начала созревания ооцитов-реципиентов) и культивировали до стадии бластоцисты. Доля раздробившихся ооцитов не различалась между экспериментальными группами и варьировала от 60,7 до 70,4 \%. Также не различалась доля развития бластоцист, когда использовалось однократное или двукратное слияние (соответственно 29,4 $\pm 4,4$ и $22,8 \pm 3,5 \%$ ). При интервале между слиянием и активацией 1,0 ч выход бластоцист составлял $17,4 \pm 2,6 \%$. Удлинение продолжительности указанного периода до 2,0 ч повышало этот показатель до $31,1 \pm 3,8$ \% (p < 0,05). В случае ранней активации (23-25 ч) доля слившихся комплексов, развившихся до стадии бластоцисты, составила $29,4 \pm 4,8 \%$. С увеличением возраста ооцитов до 26-28 ч наблюдалось снижение этого показателя до 14,6 $\pm 2,2 \%$ (р < 0,05). Таким образом, показано, что эффективность клонирования зависит от интервала между слиянием и активацией, а также возраста МII ооцитов на момент активации слившихся комплексов (оптимальные параметры применительно к описанному нами протоколу - соответственно 2 и 23-25 ч). Также очевидно, что повторное электрослияние энуклеированного ооцита и соматической клетки не оказывает отрицательного воздействия на качество образовавшихся цитогибридов, а следовательно, может быть использовано в рамках процедуры получения клонированных эмбрионов у крупного рогатого скота.

Ключевые слова: крупный рогатый скот, соматическое клонирование, слияние, активация, эмбриональное развитие.

Современные репродуктивные клеточные технологии, в частности получение клонированных эмбрионов крупного рогатого скота (КРС), имеют широкие перспективы применения для решения задач по тиражированию высокопродуктивных и уникальных генотипов в племенном животноводстве (1-4), а также созданию новых генотипов методами геномно-

* Работа выполнена при финансовой поддержке РФФИ (проект № 18-29-07089) и Министерства науки и высшего образования РФ. 
го редактирования (5-9). Однако эффективность соматического клонирования (в том числе у крупного рогатого скота) с точки зрения получения эмбрионов необходимого качества остается низкой, высока частота абортов и перинатальной смертности, а также рождения потомства с низкой жизнеспособностью, что сдерживает практическое применение такой технологии (10-12).

При клонировании взамен собственного хромосомного материала женская половая клетка (ооцит) приобретает ядро соматической клетки от животного, генетическую копию которого планируется получить. В этом случае исходный эпигенетический паттерн дифференцированных соматических клетках стирается, а эмбриональные эпигенетические характеристики и паттерны экспрессии генов восстанавливаются до тотипотентного эмбрионального состояния. Во время последующего развития полученные клонированные эмбрионы с тотипотентным статусом вновь способны дифференцироваться на различные типы соматических клеток. Этот процесс, который включает в себя различные молекулярные и эпигенетические модификации и от которого в конечном итоге зависит эффективность клонирования, называется ядерным перепрограммированием (13). Считается, что соответствующие трансформации ядра соматической клетки (кариопласта) опосредуются факторами цитоплазмы ооцита (цитопласта) и начинаются с момента объединения (слияния) ядра и цитоплазмы (14). При этом характер влияния цитоплазмы зависит от многих условий и, следовательно, может направленно изменяться (15).

Имеющиеся данные о методических приемах, повышающих эффективность получения клонированных эмбрионов, противоречивы и требуют дополнительных исследований для выбора оптимальных параметров выполняемых манипуляций. Так, нет однозначного мнения о необходимой продолжительности воздействия цитоплазмы ооцитов на донорское ядро. С одной стороны, сообщается, что для развития клонированных эмбрионов у крупного рогатого скота требуется длительное воздействие цитоплазмы ооцитов перед активацией (16), с другой - что при чрезмерно продолжительном воздействии цитоплазмы ооцитов на донорские хромосомы этот показатель ухудшается (17). Также описано снижение доли развития клонированных бластоцист по мере увеличения периода между слиянием и активацией с 1 до 5 ч (18). Ряд авторов считают оптимальным интервал 2-2,5 ч $(19,20)$.

Не менее важна с точки зрения получения жизнеспособных клонированных эмбрионов степень цитоплазматического созревания ооцита, в который интегрируется соматическая клетка. Именно поэтому наиболее подходящей клеткой-реципиентом считается созревший ооцит на стадии метафазы II (21). Однако в отсутствие активирующих стимулов в зрелых ооцитах млекопитающих инициируются процессы старения, которые негативно влияют на качество яйцеклеток и на их способность к дальнейшему эмбриональному развитию $(22,23)$. Пролонгирование культивирования созревшей яйцеклетки вследствие ее поздней активации во время процедуры переноса ядер соматических клеток, вероятно, также сопровождается комплексом внутриклеточных процессов, которые называют «старением ооцита» $(22,24)$. Однако этот аспект снижения качества яйцеклеток, к сожалению, до сих пор не учитывался при разработке научных подходов к модификации систем культивирования ооцитов in vitro, равно как и не 
детерминирован оптимальный возраст созревших яйцеклеток, используемых для клонирования (25).

Чаще всего для получения клонированных эмбрионов крупного рогатого скота осуществляют полную энуклеацию хромосом ооцита на стадии метафазы II (MII) деления мейоза с последующей инъекцией в его перивителлиновое пространство соматической клетки-донора (21). По завершении энуклеации выполняют слияние цитопласта и кариопласта в импульсном электрическом поле с пробоем мембран контактирующей пары. Дальнейшее развитие клонированных эмбрионов напрямую зависит от результативности объединения реципиента и донорской клетки, а также сохранения их жизнеспособности в процессе такого агрессивного воздействия (26). Для повышения выхода слившихся комплексов (цитогибридов) часть реконструированных ооцитов, в которых отсутствуют признаки объединения, повторно подвергают электрослиянию (27), возможные негативные последствия которого для развития клонированных эмбрионов до сих пор не охарактеризованы.

В рамках представленной работы проведена оптимизация протокола клонирования: определено необходимое время воздействия цитоплазмы ооцита на донорское ядро до активации, а также оптимальное время созревания яйцеклеток на момент их активации в составе слившихся комплексов. Кроме того, мы впервые оценили целесообразность использования повторного электрослияния для повышения эффективности объединения цитопласта и кариопласта, показав отсутствие негативного влияния этой процедуры на развитие клонированных эмбрионов крупного рогатого скота in vitro.

Цель представленной работы заключалась в оценке влияния интервала между слиянием и активацией, возраста МII ооцитов на момент их активации, а также повторного электрослияния на эффективность клонирования у крупного рогатого скота. Изучали воздействие данных факторов на формирование эмбрионов и их развитие до стадии бластоцисты.

Методика. Во всех экспериментах, кроме специально указанных случаев, использовались реагенты фирмы «Sigma-Aldrich» (США). Культивирование ооцитов и эмбрионов осуществляли при температуре $38,5{ }^{\circ} \mathrm{C}$ в атмосфере с $5 \% \mathrm{CO}_{2}$ в воздухе и $90 \%$ влажности, вне инкубатора все манипуляции с объектами проводились при $37^{\circ} \mathrm{C}$.

Подготовка донорских клеток. Донорскими клетками служили фетальные фибробласты крупного рогатого скота. Для их получения матку коров на 55-е сут стельности доставляли в лабораторию, рог матки, содержащий плод, обрабатывали 70 \% этиловым спиртом, вскрывали, извлеченный плод освобождали от головы, конечностей и внутренних органов. Полученную плодную ткань многократно отмывали в фосфатно-солевом буфеpe (ФСБ) с антибиотиками и антимикотиком (пенициллин - $100 \mathrm{ME} / \mathrm{MЛ}$, стрептомицин - 100 мкг/мл, амфотерицин - 100 нг/мл), механически измельчали и подвергали ферментативной обработке $0,25 \%$ раствором трипсина в течение 30 мин при $37{ }^{\circ}$ С. Трипсин нейтрализовали эквивалентным объемом манипуляционной среды DMEM («Gibco», США, кат. № 31966021), содержащей 5 \% фетальной бычьей сыворотки (ФБС) и гентамицин (50 мкг/мл) (DMEM-M). Отобранную суспензию клеток фильтровали через сито с диаметром пор 100 мкм и центрифугировали при 1500 об/мин в течение 5 мин. Супернатант сливали, осадок клеток ресус- 
пендировали в среде DMEM-M, повторно центрифугировали, после чего клетки культивировали до образования монослоя в чашках Петри (диаметр 100 мм) с ростовой средой DMEM («Gibco», США», кат. № 31966021), дополненной $15 \%$ ФБС, 1 \% несущественных аминокислот («Gibco», США) и гентамицином (50 мкг/мл) (DMEM-P).

Для получения необходимого количества фибробластов первичную культуру клеток размножали пассированием сформированого ими монослоя в соотношении 1:4. Для этого ростовую среду заменяли раствором трипсин/EDTA («Gibco», США), чашки инкубировали в термостате при $37{ }^{\circ} \mathrm{C}$, после чего суспензию клеток переносили в центрифужные пробирки, содержащие DMEM-M, для нейтрализации трипсина и осаждали центрифугированием при 1500 об/мин в течение 5 мин. Супернатант сливали, осадок ресуспендировали и вновь культивировали в чашках Петри диаметром 100 мм с ростовой средой DMEM-P, как описано выше. После второго пассажа клетки замораживали в среде DMEM («Gibco, CША», кат. № 31966021) с $40 \%$ ФБС и $10 \%$ диметилсульфоксида (ДМСO, DMSO) и хранили в криопробирках («Corning», США) по 1 мл при $-196{ }^{\circ} \mathrm{C}$ до использования (в течение 8 лет).

По необходимости (за 7 сут до процедуры клонирования) криопробирку с клетками размораживали в водяной бане при $37{ }^{\circ} \mathrm{C}$, содержимое переносили в центрифужную пробирку с 10 мл DMEM-M и центрифугировали при 1500 об/мин. После этого клетки культивировали в DMEM-P до завершения формирования монослоя и контактно ингибировали в течение 2 сут с целью синхронизации клеточного цикла. Не ранее чем за 30 мин до переноса в энуклеированный ооцит готовили клеточную суспензию в среде ТС199, содержащей 10 \% ФБС и гентамицин (50 мкг/мл) (ТС199-М).

Подготовка ооцитов-реципиентов. Яичники коров, отобранные после убоя, доставляли в лабораторию в течение 3-5 ч при 30-35 $\mathrm{C}$, освобождали от окружающих тканей и многократно отмывали в стерильном физиологическом растворе с антибиотиками (пенициллин - $100 \mathrm{ME} / \mathrm{Mл}$, стрептомицин - 50 мкг/мл). Ооцит-кумулюсные комплексы (ОКК) выделяли из фолликулов, промывали 3 раза в среде ТС199-М с гепарином (10 мкг/мл) и проводили морфологическую оценку извлеченных ОКК. Для культивирования использовали ооциты округлой формы, с гомогенной цитоплазмой, равномерной по ширине зоной пеллюцида и многослойным компактным кумулюсом. Для созревания ооцитов отобранные по качеству ОКК в течение 19-23 ч культивировали группами по 20-30 шт. в 500 мкл среды ТС-199, содержащей 10 \% ФБС, 1 мМ пируват натрия, гентамицин (50 мкг/мл), ФСГ (10 мкг/мл) и ЛГ (10 мкг/мл).

Реконструирование созревших ооцитов. Созревшие ооциты освобождали от клеток кумулюса, инкубируя ОКК в $0,1 \%$ растворе гиалуронидазы (в среде ТС199-М) в течение 1 мин при $37{ }^{\circ} \mathrm{C}$, с последующей дезагрегацией комплексов пипетированием. Для клонирования отбирали только ооциты с первым полярным тельцем (ППТ).

Микрохирургические манипуляции (в группах по 15-20 ооцитов) проводили в каплях среды ТС199-М объемом 20 мкл, которые наносили на дно чашек Петри, покрытое слоем легкого минерального масла. Процедуру проводили с использованием инвертированного микроскопа Diafort («Nikon Corporation», Япония), совмещенного с микроманипуляционной системой Narishige (Япония). В процессе реконструирования ооциты фо- 
кусировали с помощью удерживающей пипетки в поле зрения микроскопа в положении, позволяющем четко визуализировать ППТ в перивителлиновом пространстве ооцита в направлении на 1 или 5 ч условного циферблата. Микропипетку для биопсии (внутренний диаметр 13-15 мкм) подводили вплотную к оболочке ооцитов, прокалывали зону пеллюцида в месте локализации ППТ, хромосомы яйцеклетки удаляли вслепую аспирацией ППТ и 10-20 \% прилежащей цитоплазмы. Соматическую клетку вводили в перивителлиновое пространство зафиксированного ооцита микропипеткой, используемой ранее для биопсии ППТ, через отверстие, сформированное в процессе энуклеации.

Для получения клонированного цитогибрида энуклеированный ооцит и соматическую клетку подвергали электрослиянию с использованием мультипоратора фирмы «Eppendorf» (Великобритания). Комплексы ооцит/соматическая клетка помещали в микрокамеру, предварительно заполненную буфером (270 мМ маннитол, 0,1 мМ $\mathrm{MgSO}_{4}, 0,05 \mathrm{MM} \mathrm{CaCl}_{2}$ ), с расстоянием между электродами 0,2 мм и воздействовали сначала электрическим полем переменного тока (5 B, 5 с) для расхождение клеточных комплексов к электродам, затем двумя последовательными прямоугольными импульсами постоянного тока (35 B, 20 мкс). Обработанные таким образом клеточные комплексы для кратковременного культивирования переносили в капли среды ТС199-М объемом 50 мкл, покрытые слоем легкого минерального масла. Через 1 ч инкубации оценивали образование из комплексов ооцит/соматическая клетка морфологически нормальных клонированных цитогибридов и проводили их отбор. Для части комплексов, в которых отсутствовали признаки объединения ооцита и соматической клетки, процедуру электрослияния повторяли еще раз как описано выше.

Активация и постактивационное культивирование клонированных цитогибридов. Полученные цитогибриды активировали через 1 или 2 ч после слияния (23-25 или 26-28 ч с момента начала созревания ооцитов-реципиентов) посредством инкубации в течение 5 мин в растворе Тироде (28), содержащем 5 мМ иономицина, с последующим культивированием реконструированных ооцитов в среде CRlaa (29) с 6диметиламинопурином (2 мМ) и циклогекседином (10 мкг/мл). Через 4 ч предполагаемые зиготы переносили в среду CR1aа и культивировали в течение 4 сут, после чего развивающиеся эмбрионы помещали в ту же среду, содержащую 5 \% ФБС. На 2-е сут после активации цитогибридов морфологически оценивали раздробившиеся зиготы, на 7-е сут определяли число эмбрионов, развившихся до стадии бластоцисты. Оценку выполняли под стереомикроскопом SMZ («Nikon», Япония) при увеличении ×40.

Статистическую обработку данных проводили методом однофакторного дисперсионного анализа при помощи компьютерной программы SigmaStat («Systat Software, Inc.», США). Результаты экспериментов представлены в виде средних значений $(M)$ и стандартных ошибок средних $( \pm \mathrm{SEM})$. Для оценки достоверности различий между сравниваемыми средними значениями использовали критерий Тьюки $(\mathrm{p} \leq 0,05)$.

Результаты. Этапы подготовки фетальных фибробластов и ооцитов крупного рогатого скота к процедуре клонирования иллюстрирует рисунок 1 (а - сформированный монослой при получении донорских клеток, б - приготовление суспензии фетальных фибробластов, в - отбор ооцитов с первым полярным тельцем). 
Известно, что время воздействия цитоплазмы ооцитов на донорское ядро перед активацией критично для последующего развития клонированных эмбрионов $(18,20)$. Под влиянием факторов цитоплазмы в ядре соматической клетки (с момента его интеграции в цитопласт при слиянии) инициируются процессы перепрограммирования, которые необходимы для возвращения клетки в тотипотентное состояние (21).

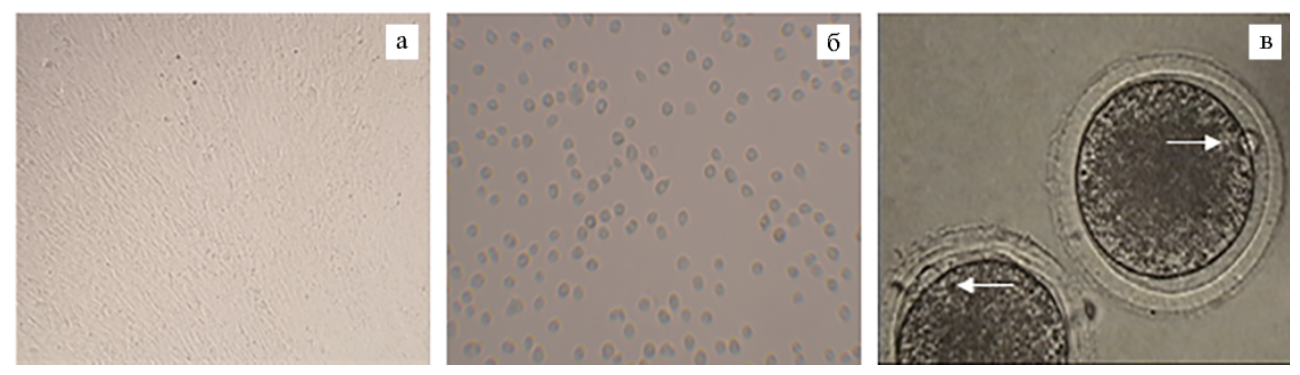

Рис. 1. Микрофотографии фетальных фибробластов и ооцитов крупного рогатого скота на этапах подготовки к процедуре переноса ядер соматических клеток (somatic cell nuclear transfer, SCNT): a - культура фетальных фибробластов через 2 сут контактного ингибирования; б фетальные фибробласты в виде суспензии (увеличение $\times 200$ ); в - ооциты коров на стадии метафазы II (белой стрелкой обозначено первое полярное тельце, увеличение ×400). Микроскоп Eclipse Ti-U («Nikon», Япония).
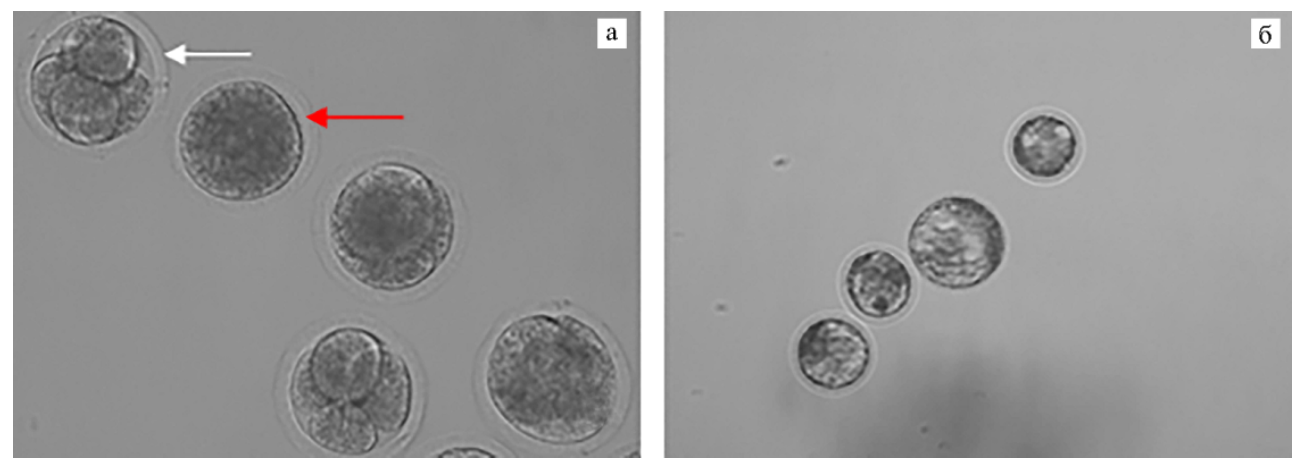

Рис. 2. Микрофотографии клонированных эмбрионов крупного рогатого скота, полученных в результате слияния энуклеированных МII ооцитов и соматических клеток (фетальных фибробластов), с последующей активацией образовавшихся цитогибридов: а - слившиеся (красная стрелка) и раздробившиеся (белая стрелка) цитогибриды (увеличение $\times 200)$; б - цитогибриды, развившиеся до стадии бластоцисты (увеличение ×100). Микроскоп Eclipse Ti-U («Nikon», Япония).

В представленной работе мы оценили влияние интервала между слиянием и активацией (1 или 2 ч) на перепрограммирование соматического ядра по способности активированных цитогибридов $(n=142)$ вступать в первое деление дробления (рис. 2, а) и достигать стадии бластоцисты (см. рис. 2, б). Доля раздробившихся ооцитов на 2-е сут культивирования не различалась между экспериментальными группами и для интер-

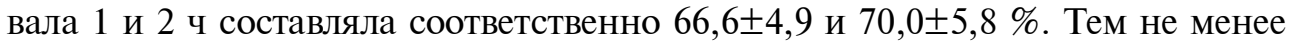
мы обнаружили, что продолжительность воздействия цитоплазмы ооцита на донорское ядро до активации оказывает эффект на развитие цитогибрида до стадии бластоцисты. При интервале 1,0 ч выход бластоцист составлял $17,4 \pm 2,6 \%$, тогда как более продолжительное воздействие (2,0 ч) достоверно повышало этот показатель до $31,1 \pm 3,8 \%$ (р < 0,05) (рис. 3$)$.

Наши данные частично согласуются с результатами других авторов $(19,20,30)$ и свидетельствуют о том, что 2-часовой интервал между слия- 
нием и активацией обеспечивает донорское ядро достаточным воздействием цитоплазмы МII ооцита, чтобы инициировать события перепрограммирования, а 1-часовой интервал приводит к снижению развития клонированных эмбрионов до стадии бластоцисты. О положительном влиянии 2-часового воздействия цитоплазмы ооцита на донорское ядро также сообщали K.I. Aston с соавт. (20), но при этом ими обнаружен сходный результат и для 1-часового воздействия. Возможно, такие различия обусловлены особенностями используемых для клонирования соматических клеток. В наших экспериментах это были фетальные фибробласты с длительным сроком хранения.

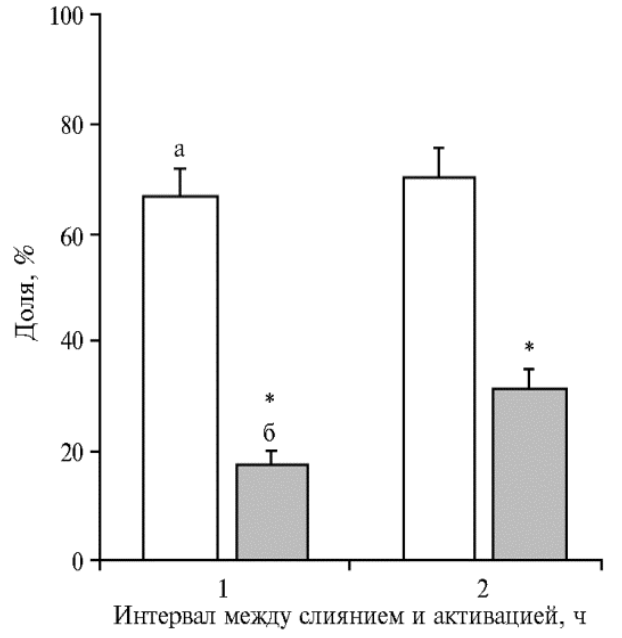

Рис. 3. Влияние временно́го интервала между слиянием кариопласта с ооцитом и активацией на развитие клонированных эмбрионов крупного рогатого скота in vitro: a - доля дробления, б доля бластоцист. Число независимых экспериментов $n=6$, вертикальные отрезки - стандартные ошибки средних $( \pm \mathrm{SEM})$. Звездочкой (*) отмечены статистически значимые различия между сравниваемыми группами при р $<0,05$.

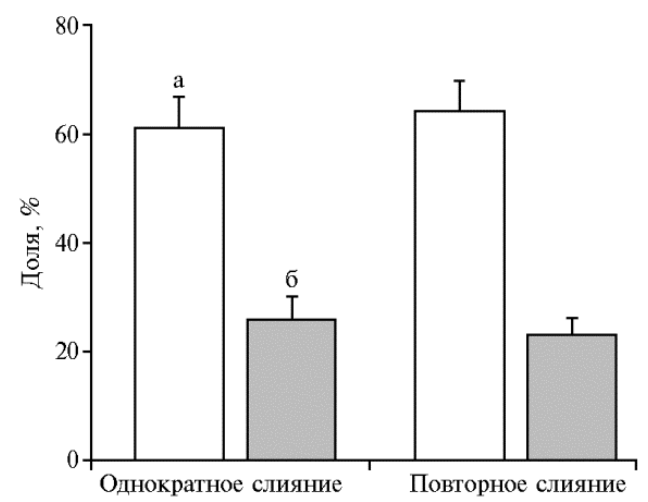

Рис. 5. Влияние процедуры повторного электрослияния энуклеированного ооцита и соматической клетки на последующее развитие клонированных эмбрионов до стадии бластоцисты: $\mathrm{a}$ - доля дробления, б - доля бластоцист. Число независимых экспериментов $n=9$, вертикальные отрезки - стандартные ошибки средних $( \pm \mathrm{SEM})$.

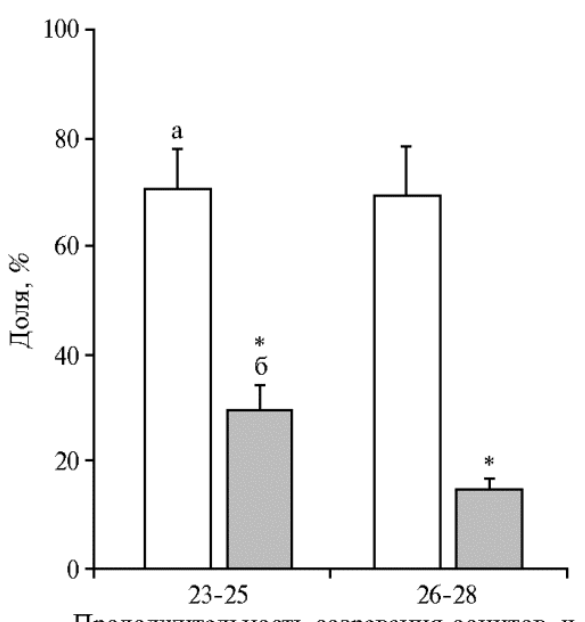

Рис. 4. Влияние возраста МII ооцита в период активации на развитие клонированных цитогибридов до стадии бластоцисты: а - доля дробления, б - доля бластоцист. Число независимых экспериментов $n=9$, вертикальные отрезки - стандартные ошибки средних $( \pm \mathrm{SEM})$. Звездочкой (*) отмечены статистически значимые различия между сравниваемыми группами при $\mathrm{p}<0,05$.

Важным условием формирования способного к нормальному развитию клонированного эмбриона является степень цитоплазматического созревания исходных половых клеток (21). В этой связи в практике соматического клонирования в качестве клетки-реципиента чаще всего используют ооциты на стадии метафазы II, так как в их цитоплазме в силу соответствующих цитоплазматических преобразований присутствуют факторы, от которых зависит формирование в клонированных цитогибридах необходимых эмбриональных компетенций (21, 24). Тем не менее показано, что в завершивших ядерное созревание 
ооцитах в отсутствие активирующих стимулов инициируются процессы старения, негативно влияющие на качество яйцеклеток $(22,23)$, следовательно, возраст МII ооцитов на момент активации цитогибридов также может критически влиять на развитие клонированных эмбрионов $(24,25)$.

Мы сравнили компетенции к эмбриональному развитию у двух групп цитогибридов, активированных через 23-25 ч $(n=104)$ и через 2628 ч $(n=78)$ с начала созревания ооцитов-реципиентов (рис. 4). Доля раздробившихся ооцитов не различалась между вариантами и находилась в пределах от 69,4 до 70,4 \%. В случае ранней активации доля цитогибри-

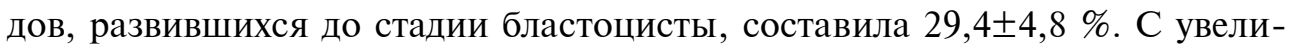
чением возраста ооцитов до 26-28 ч анализируемый показатель достоверно снижался до $14,6 \pm 2,2$ \% $(\mathrm{p}<0,05)$. Полученные нами данные свидетельствуют о негативном влиянии пролонгированного культивирования зрелых ооцитов - источников цитопластов на развитие клонированных эмбрионов крупного рогатого скота, а также о том, что возраст MII ооцитов на момент их активации в составе гибридных комплексов не должен превышать 26 ч. О преимуществе более ранней активации с точки зрения получения жизнеспособного потомства ранее сообщали и другие авторы $(25,31)$.

Мы также исследовали влияние повторного слияния энуклеированного ооцита и соматической клетки на последующее развитие клонированных эмбрионов (рис. 5). Для этого комплексы, в которых через 1 ч после первого слияния отсутствовали признаки объединения цитопласта и кариопласта, подвергали повторному электрослиянию, используя те же параметры, что и при первой процедуре. Анализ развития полученных клонированных эмбрионов in vitro не выявил негативного влияния дополнительного воздействия электроимпульсом на долю раздробившихся цитогибридов. Также не наблюдалось снижения их потенциала к развитию до стадии бластоцисты $(29,4 \pm 4,4$ и $22,8 \pm 3,5$ \% соответственно для однократного и двукратного слияния).

В практике соматического клонирования повторное электрослияние используется для получения большего количества клеточных комплексов с признаками объединения энуклеированного ооцита и донорской клетки (27), а также как метод активации цитогибридов (31). При этом, учитывая возможные негативные последствия повторного электрослияния, как правило, прибегают к более щадящим режимам электрического импульса. В нашем исследовании для слияния цитопласта и кариопласта использовались сходные с первым воздействием параметры, тем не менее ухудшения в развитии клонированных эмбрионов до стадии бластоцисты мы не наблюдали.

Таким образом, нами подтверждено, что эффективность получения клонированных эмбрионов крупного рогатого скота предымплантационных стадий развития зависит от интервала между слиянием и активацией, а также от возраста МII ооцитов на момент активации цитогибридов. Оптимальные значения этих параметров (применительно к описанному нами протоколу) - соответственно 2 ч и 23-25 ч. Также очевидно, что повторное электрослияние энуклеированного ооцита и соматической клетки не оказывает отрицательного воздействия на качество образовавшихся цитогибридов, а следовательно может быть использовано в рамках процедуры получения клонированных эмбрионов у крупного рогатого скота. 
142132 Россия, Московская обл., г.о. Подольск, пос. Дубровицы, 60, e-mail: g_singina@mail.ru $₫$, vubi_myaso@mail.ru, shedvek@yandex.ru

\title{
in vitro DEVELOPMENT OF CLONED EMBRYO IN CATTLE IN RELATION WITH FUSION AND ACTIVATION PARAMETERS
}

\author{
G.N. Singina, A.V. Lopukhov, E.N. Shedova
}

\author{
Ernst Federal Science Center for Animal Husbandry, 60, pos. Dubrovitsy, Podolsk District, Moscow Province, \\ 142132 Russia, e-mail g_singina@mail.ru ( $\square$ corresponding author), shedvek@yandex.ru \\ ORCID: \\ Singina G.N. orcid.org/0000-0003-0198-9757 \\ Lopukhov A.V. orcid.org/0000-0002-1284-1486 \\ Shedova E.N. orcid.org/0000-0002-9642-2384 \\ The authors declare no conflict of interests \\ Acknowledgements: \\ Supported financially by the Russian Foundation for Basic Research (project No. 18-29-07089) and the Ministry of \\ Science and Higher Education of the Russian Federation \\ Received December 17, 2019 \\ doi: 10.15389 /agrobiology.2020.2.295eng
}

\section{Abstract}

Embryo production through somatic cloning technology has the perspectives for application in reproductive biotechnologies in cattle in order to multiply the most productive and unique genotypes in livestock breeding and create new genotypes using genome editing. Success of somatic cloning depends on the ability of donor somatic cell nucleus (karioplast) to be reprogrammed to totipotent state. Relevant transformations of donor nucleus are mediated by oocyte cytoplasmic factors (cytoplasts) and start from the moment of their association (fusion). Effects of oocyte cytoplasm are direct and depend on many factors. The objective of the present study was to evaluate the cloning efficiency in terms of time of oocyte cytoplasm exposure to donor nucleus before activation, the time of oocyte maturation before their activation in the fused complexes (cytohybrids), and repeated electrofusion of the cytoplast and karyoplast. The effects of these factors on formation of cloned embryos and development to blastocyst stage were studied. Isolated oocyte-cumulus complexes (OCCs) were in vitro matured in TC-199 medium supplemented with $10 \%$ fetal bovine serum, $10 \mu \mathrm{g} / \mathrm{ml}$ of FSH and $10 \mu \mathrm{g} / \mathrm{ml}$ of LH. After 20-24 h of maturation, OCCs were treated with a $0.1 \%$ hyaluronidase, then cumulus cells were mechanically removed and the oocytes with the first polar body were selected. Long-time conserved fetal fibroblasts were in vitro cultured up to monolayer and maintained in contact inhibition during 2 days. Then, cell suspension was prepared for transferring into enucleated oocyte. Somatic cell was transferred to perivitelline space of the oocyte, and two consecutive rectangular $20 \mu$ s pulses at constant current with a voltage of $35 \mathrm{~V}$ were performed (once or twice if there were no signs of cell-oocyte fusion). The obtained cytohybrids were activated with the ionomycin 1 or 2 hours after fusion (recipient oocytes were matured either 23-25 hours or 26-28 hours). Activated cytohybrides were then cultured up to blastocyst stage. Oocyte cleavage rate were similar in all experimental groups (60.7 to $70.4 \%$ ). Blastocyst development rate did not differ between the groups where single or double fusions were performed $(29.4 \pm 4.4$ and $22.8 \pm 3.5 \%$, respectively). Blastocyst rate was $17.4 \pm 2.6 \%$ at 1 -hour interval between fusion and activation. Twohour interval increased blastocyst rate to $31.1 \pm 3.8 \%(\mathrm{p}<0.05)$. In the case of early activation (23-25 hours of maturation), $29.4 \pm 4.8 \%$ of fused complexes developed to the blastocyst stage. With an increase of oocyte maturation time to $26-28$ hours, blastocyst rate decreased to $14.6 \pm 2.2 \%$ $(\mathrm{p}<0.05)$. Therefore, cloning efficiency depends on the interval between cytohybrid fusion and activation, and the age of MII oocytes at the time of activation of the fused complexes; 2 hours and 23-25 hours, respectively, were the optimal parameters. In addition, the repeated electrofusion of the enucleated oocytes and somatic cells did not affect cytohybrid quality, and, therefore, this procedure can be used for somatic embryo cloning in cattle.

Keywords: cattle, somatic cell nuclear transfer, fusion, activation, embryo development.

\section{R E F E R E N C E S}

1. Tian X.C., Kubota C., Sakashita K., Izaike Y., Okano R., Tabara N., Curchoe C., Jacob L., Zhang Y., Smith S., Bormann C., Xu J., Sato M., Andrew S., Yang X. Meat and milk compo- 
sitions of bovine clones. Proceedings of the National Academy of Sciences, 2005, 102(18): 62616266 (doi: 10.1073/pnas.0500140102).

2. Hoshino Y., Hayashi N., Taniguchi S., Kobayashi N., Sakai K., Otani T., Iritani A., Saeki K. Resurrection of a bull by cloning from organs frozen without cryoprotectant in a $-80{ }^{\circ} \mathrm{S}$ freezer for a decade. PLoS ONE, 2009, 4(1): e4142 (doi: 10.1371/journal.pone.0004142).

3. Yonai M., Kaneyama K., Miyashita N., Kobayashi S., Goto Y., Bettpu T., Nagai T. Growth, reproduction, and lactation in somatic cell cloned cows with short telomeres. Journal of Dairy Science, 2005, 88(11): 4097-4110 (doi: 10.3168/jds.S0022-0302(05)73094-0).

4. Van Eenennaam A.L. Application of genome editing in farm animals: cattle. Transgenic Research, 2019, 28(2): 93-100 (doi: 10.1007/s11248-019-00141-6).

5. Brophy B., Smolenski G., Wheeler T., Wells D., L'Huillier P., Laible G. Cloned transgenic cattle produce milk with higher levels of beta-casein and kappa-casein. Nature Biotechnology, 2003, 21(2): 157-162 (doi: 10.1038/nbt783).

6. Richt J.A., Kasinathan P., Hamir A.N., Castilla J., Sathiyaseelan T., Vargas F., Sathiyaseelan J., Wu H., Matsushita H., Koster J., Kato S., Ishida I., Soto C., Robl J.M., Kuroiwa Y. Production of cattle lacking prion protein. Nature Biotechnology, 2007, 25(1): 132-138 (doi: $10.1038 /$ nbt1271).

7. Wu H., Wang Y., Zhang Y., Yang M., Lv J., Liu J., Zhang Y. TALE nickase-mediated SP110 knocking endows cattle with increased resistance to tuberculosis. Proceedings of the National Academy of Sciences, 2015, 112(13): E1530-E1539 (doi: 10.1073/pnas.1421587112).

8. Proudfoot C., Carlson D.F., Huddart R., Long C.R., Pryor J.H., King T.J., Lillico S.G., Mileham A.J., McLaren D.G., Whitelaw C.B., Fahrenkrug S.C. Genome edited sheep and cattle. Transgenic Research, 2015, 24(1): 147-153 (doi: 10.1007/s11248-014-9832-x).

9. Gao Y., Wu H, Wang Y, Liu X, Chen L, Li Q., Cui C., Liu X., Zhang J., Zhang Y. Single Cas9 nickase induced generation of NRAMP1 knockin cattle with reduced off-target effects. Genome Biology, 2017, 18(1): 13 (doi: 10.1186/s13059-016-1144-4).

10. Farin P.W., Piedrahita J.A., Farin C.E. Errors in development of fetuses and placentas from in vitro-produced bovine embryos. Theriogenology, 2006, 65(1): 178-191 (doi: 10.1016/j.theriogenology.2005.09.022).

11. Bertolini M., Bertolini L.R., Gerger R.P.C., Batchelder C.A., Anderson G.B. Developmental problems during pregnancy after in vitro embryo manipulations. Rev. Bras. Reprod. Anim., 2007, 31(3): 391-405.

12. Su J., Wang Y., Liu Q., Yang B., Wu Y., Luo Y., Hu G., Zhang Y. Aberrant mRNA expression and DNA methylation levels of imprinted genes in cloned transgenic calves that died of large offspring syndrome. Livestock Science, 2011, 141(1): 24-35 (doi: 10.1016/j.livsci.2011.04.012).

13. Yang X.Z., Smith S.L., Tian X.C., Lewin H.A., Renard J.P., Wakayama T. Nuclear reprogramming of cloned embryos and its implications for therapeutic cloning. Nature Genetics, 2007, 39(3): 295-302 (doi: 10.1038/ng1973).

14. Latham K.E. Early and delayed aspects of nuclear reprogramming during cloning. Biology of the Cell, 2005, 97(2): 119-132 (doi: 10.1042/BC20040068).

15. Akagi S., Matsukawa K., Takahashi S. Factors affecting the development of somatic cell nuclear transfer embryos in cattle. Journal of Reproduction and Development, 2014, 60(5): 329-335 (doi: 10.1262/jrd.2014-057).

16. Wells D.N., Misica P.M., McMillan W.H., Tervit H.R. Production of cloned bovine fetuses following nuclear transfer using cells from a fetal fibroblast cell line. Theriogenology, 1998, 49(1): 330 (doi: 10.1016/S0093-691X(98)90683-5).

17. Akagi S., Yokota M., Neguebi T., Taniyama A., Fuebimoto D., Izaile Y. The timing of fusion and chemical activation in nuclear transfer affects development potential of bovine embryos. Theriogenology, 2001, 55(1): 252 (doi: 10.1016/S0093-691X(00)00457-X).

18. Choi J.Y., Kim C.I., Park C.K., Yang B.K., Cheong H.T. Effect of activation time on the nuclear remodeling and in vitro development of nuclear transfer embryos derived from bovine somatic cells. Molecular Reproduction and Development, 2004, 69(3): 289-295 (doi: 10.1002/mrd.20131).

19. Liu L., Shin T., Pryor J.H., Kraemer D., Westhusin M. Regenerated bovine fetal fibroblasts support high blastocyst development following nuclear transfer. Cloning, 2001, 3(2): 51-58 (10.1089/15204550152475554).

20. Aston K.I., Li G.P., Hicks B.A., Sessions B.R., Pate B.J., Hammon D., Bunch T.D., White K.L. Effect of the time interval between fusion and activation on nuclear state and development in vitro and in vivo of bovine somatic cell nuclear transfer embryos. Reproduction, 2006, 131(1): 45-51 (doi: 10.1530/rep.1.00714).

21. German S.D., Campbell K.H.S. Livestock somatic cell nuclear transfer. In: Sustainable food production. P. Christou, R. Savin, B.A. Costa-Pierce, I. Misztal, C.B.A. Whitelaw (eds.) Springer, New York, 2013: 1067-1095 (doi: 10.1007/978-1-4614-5797-8_2). 
22. Miao Y.L., Kikuchi K., Sun G.Y., Schatten H. Oocyte aging: cellular and molecular changes, developmental potential and reversal possibility. Human Reproduction Update, 2009, 15(5): 573585 (doi: 10.1093/humupd/dmp014).

23. Lebedeva I.Yu., Singina G.N., Lopukhov A.V., Zinovieva N.A. Dynamics of morphofunctional changes in aging bovine ova during prolonged culture in vitro. Cell and Tissue Biology, 2014, 8(3): 258-266 (doi: 10.1134/S1990519X14030080).

24. Akagi S., Geshi M., Nagai T. Recent progress in bovine somatic cell nuclear transfer. Animal Science Journal, 2013, 84(3): 191-199 (doi: 10.1111/asj.12035).

25. Akagi S., Matsukawa K., Takahashi S. Factors affecting the development of somatic cell nuclear transfer embryos in cattle. Journal of Reproduction and Development, 2014, 60(5): 329-335 (doi: 10.1262/jrd.2014-057).

26. Singina G.N., Lopukhov A.V., Zinov'eva N.A., Shapkanova E.V., Puzik A.A. Optimization of parameters of the oocyte enucleation and fusion with the somatic cell during production of mammalian cloned embryos. Sel'skokhozyaistvennaya biologiya [Agricultural Biology], 2013, 2: 46-51 (doi: 10.15389/agrobiology.2013.2.46eng).

27. Ross P.J., Cibelli J.B. Bovine somatic cell nuclear transfer. In: Cellular programming and reprogramming. Methods in molecular biology (methods and protocols). S. Ding (ed.). Humana Press, 2010, V. 636: 155-177 (doi: 10.1007/978-1-60761-691-7 10).

28. Bavister B.D., Liebfried M.L., Lieberman G. Development of preimplantation embryos of the golden hamster in a defined culture medium. Biology of Reproduction, 1993, 28(1): 235-247 (doi: 10.1095/biolreprod28.1.235).

29. Rosenkrans C.F.Jr., First N.L. Effect of free amino acids and vitamins on cleavage and develop-mental rate of bovine zygotes in vitro. Journal of Animal Science, 1994, 72(2): 434-437 (doi: $10.2527 / 1994.722434 x)$.

30. Liu J., Wang Y., Su J., Wang L., Li R., Li Q., Wu Y., Hua S., Quan F., Guo Z., Zhang Y. Effect of the time interval between fusion and activation on epigenetic reprogramming and development of bovine somatic cell nuclear transfer embryos. Cellular Reprogramming, 2013, 15(2): 134-142 (doi: 10.1089/cell.2012.0052).

31. Shen P.C., Lee S.N., Liu B.T., Chu F.H., Wang C.H., Wu J.S., Lin H.H., Cheng W.T.K. The effect of activation treatments on the development of reconstructed bovine oocytes. Animal Reproduction Science, 2008, 106(1-2): 1-12 (doi: 10.1016/j.anireprosci.2007.03.019). 